\title{
PENGARUH POLA ASUH ORANG TUA TERHADAP KEMANDIRIAN DAN KEMAMPUAN REGULASI EMOSI ANAK USIA DINI
}

\author{
Sarah Emmanuel Haryono \\ Prodi PG-PAUD, Fakultas Ilmu Pendidikan, Universitas Kanjuruhan Malang, \\ sarah.emmanuel@unikama.ac.id \\ Henni Anggraini \\ Prodi PG-PAUD, Fakultas Ilmu Pendidikan, Universitas Kanjuruhan \\ Malang,hennianggraini@unikama.ac.id \\ Siti Muntomimah \\ Prodi PG-PAUD, Fakultas Ilmu Pendidikan, Universitas Kanjuruhan Malang, \\ muntomimah@unikama.ac.id
}

\begin{abstract}
Parenting is the way parents to educated their children. Each parent has different educational habits. Parenting patterns applied by parents in a family also vary, it is strongly influenced by how parents want to treat their children. In general, there are 3 parenting patterns, namely: authoritative, permissive, and democratic. When parents agree to apply the pattern of parenting that is considered the most ideal for their children, then the pattern of parenting that will apply the pattern of personality and habits within the child. In carrying out the parenting process of a parent child can provide an opportunity for the child to serve his needs on the simple side of things, as: when a one-year-old child begins to learn to hold a spoon and feed the food into his mouth by himself, in the supervision of his parents. Autonomy must be nurtured from an early age, and it is expected that autonomy can develop within the child. In developing the pattern of self-awareness in early childhood, as stated by Havinghurst that within a child there is an ability to make arrangements fortheir emotion that is nothing but the ability to perform emotional regulation. In this study, researchers want to know how much influence of adopted parenting by the elderly on independence and emotional regulatory ability in early childhood. The design used in this study is quantitative, by developing 3 kinds of scale instruments, namely: the scale of parenting, the scale of autonomy, and the scale of emotional regulation. The scale is used to measure each of the variables present in this research. The result of hypothesis test using anova formula, with the help of SPSS.17, shows a significance value of 0.002 with a significance level of $0.05(95 \%)$, indicating that there is a significant influence of parenting pattern on the independence and emotional regulation ability of the child early.
\end{abstract}

Keyword : parenting style, autonomy, emotional regulation 
Jurnal Warna : Jurnal Pendidikan Dan Pembelajaran Anak Usia dini. Maret 2018. Vol 03. No. 01

\section{PENDAHULUAN}

Setiap keluarga mempunyai pola kehidupan keluarga dengan perbedaan budaya, peran yang dimainkan sebagai anggota keluarga, dan metode pendidikan yang berbeda-beda.Orang tua memiliki peranan yang penting didalam pengasuhan, perawatan, dan pendidikan bagi anak.

Kehidupan didalam keluarga akan mempengaruhi secara mendasar pola pengasuhan terhadap anak-anak mereka.

Setiap keluarga mempunyai pola gaya pengasuhan yang berbeda.

Secara umum dapat diartikan bahwa pola asuh adalah pola interaksi antara orang tua dengan anak. Cara pengasuhan anak ini meliputi bagaimana sikap atau perilaku orang tua saat berhubungan dengan anak. Menurut Hoghuni (2004) pola asuh orang tua merupakan pola interaksi antara anak dengan orang tua yang meliputi bukan hanya pemenuhan kebutuhan fisik (makan, minum, pakaian, dan lain sebagainya) dan kebutuhan psikologis (afeksi atau perasaan) tetapi juga norma-norma yang berlaku di masyarakat agar anak dapat hidup selaras dengan lingkungan.

Pola yang diterapkan oleh orang tua terhadap anak-anaknya didalam keluarga akan membentuk karakter anak-anak mereka. Diana Baumrind ( dalam Santrock,2009) menyataka bahwa orang tua tidak boleh menghukum atau menjauh dari anak. Ada 3 macam pola asuh menurut Hurlock (1999), yaitu : 1. Pola Asuh Otoriter Pola asuh ini cenderung menetapkan standar yang mutlak harus dituruti, biasanya dibarengi dengan ancaman-ancaman. Pola asuh ini menitikberatkan orang tua sebagai pemegang kekuasaan penuh, misalnya dalam pergaulan maupun pemilihan sekolah. Pengawasan dilakukan dengan ketat dan bersifat membatasi, karena anak masih dianggap sebagai anak kecil. Apabila anak tidak mau melakukan apa yang dikatakan oleh orang tua, maka orang tua tipe ini tidak segan menghukum anak. 2. Pola Asuh Demokratis. Pola asuh ini berorientasi pada tujuan dan cita-cita anak sehingga anak berkembang menurut keinginannya, Namun tetap ada bimbingan dan pengawasan yang dilakukan secara tegas tetapi tidak terlalu membatasi. Orang tua dengan pola asuh ini bersikap rasional, selalu mendasari tindakannya pada rasio atau pemikiran-pemikiran. Orang tua tipe ini juga bersikap realistis terhadap kemampuan anak, tidak berharap yang berlebihan yang melampaui kemampuan anak. Orang tua tipe ini juga memberikan kebebasan kepada anak untuk memilih dan melakukan suatu tindakan, dan pendekatannya kepada anak bersifat hangat. pola asuh ini tetap menanamkan kendali yang tinggi pada anak namun disertai 
Jurnal Warna : Jurnal Pendidikan Dan Pembelajaran Anak Usia dini. Maret 2018. Vol 03. No. 01

dengan sikap demokratis. Orang tua memeberikan kesempatan kepada anak untuk mengemukakan pendapatnya dan memilih apa yang paling disukainya. Dengan kata lain memberikan kebebasan yang bertanggung jawab. 3. Pola Asuh Permisif. orang tua memberikan kebebasan kepada anak dalam melakukan aktivitasnya, tipe orang tua seperti ini memiliki kontrol yang rendah terhadap anak dan jarang memberikan hukuman kepada anaknya.

Pola asuh permisif pada umumnya tidak ada penjelasan sedikitpun tentang tutntutan dan displin. Anak-anak dibiarkan mengatur tingkah laku sendiri dan membuat keputusan sendiri. Oramg tua serba membebaskan tanpa mengendalikan, pola asuh seperti ini lemah dalam hal mendisiplinkan anak.

Kenyataan yang terjadi didalam kehidupana keluarga adalah orang tua kurang memahami dampak dari pola asuh yang diterapkan terhadap anak-anaknya. Pengasuhan yang baik membutuhkan waktu dan usaha. Orang tua tidak bisa melakukannya dalam waktu yang singkat, bukan hanya jumlah waktu yang dihabiskan orang tua bersama anak tetapi yang penting bagi perkembangan anak adalah bagaimana kualitas pengasuhan yang diterapkan oleh orang tua.

Setiap orang tua memiliki kulaitas pengasuhan yang berbeda-beda, didalam menjalankan proses pengasuhan terhadap anak orang tua dapat memberikan kesempatan kepada anak untuk melayani kebutuhan dirinya dimuali dari hal-hal yang sederhana, seperti halnya : ketika anak berusia satu tahun, anak mulai belajar untuk memegang sendok makan dan memasukan makanan kedalam mulutnya secara mandiri walaupun tetap didalam pengawasan orang tuanya.

Kemandirian merupakan bagian dari tugas perkembangan anak melalui proses pengasuhan. Brooks ,2001 (dalam Dewanggi ,2012) menyatakan beberapa tujuan didalam pengasuhan yaitu: (1) menjamin kesehatan fisik ( gizi dan kesehatan) dan kelangsungan hidup anak , (2) menyiapkan agar anak menjadi orang dewasa yang mandiri, dan bertanggung jawab baik secara ekonomi, sosial, dan moral, (3) mendorong perilaku yang positif , termasuk cara penyesuaian diri, kemampuan intelektual, kemampuan berinteraksi sosial dengan orang lain agar dapat bertanggung jawab dan bermanfaat bagi lingkungan sekitar.

Kemandirian dapat dimulai sejak usia dini bagi seorang anak, tergantung bagaimana orang tua menerapkannya. Kemandirian merupakan hal yang penting didalam kehidupan seorang anak agar nantinya dia tidak terlalu bergantung 
kepada orang tuanya ataupun orang dewasa lainnya.

kemandirian

merupakan

kemampuan atau keterampilan yang dimiliki oleh anak untuk melakukan segala sesuatunya sendiri, baik yang terkait dengan aktivitas bantu diri maupun aktivitas kesehariannya tanpa tergantungan dengan orang lain. Kemandirian anak usia dini dalam melakukan prosedur-prosedur keterampilan merupakan kemampuan melakukan aktivitas sederhana sehari-hari seperti makan tanpa harus disuapi, mampu memakai kaos kaki dan baju sendiri, bisa buang air besar/kecil sendiri, mampu memakai baju dan celana sendiri ( Suardani, 2016).

ciri-cirikemandirian anak usia dini adalah seorang anak yang memiliki rasatanggung jawab dan kepercayaan diri, mampu dan mudah menyesuaikan diridengan lingkungan, memiliki rasa ingintahu yang tinggi dan selalu inginmencoba sesuatu, tidak bergantung lagi dengan orang dewasa, selaluberusaha untuk melakukan sendiri selagi anak mampu, serta memilikimotivasi untuk memilih maupun melakukan sesuatu yang anak inginkan.

Karakteristik Perilaku Mandiri menurut Suharman (2012) adalah sebagai berikut:
1) Mengambil Inisiatif untuk Bertindak.

Orang yang mandiri memiliki kecenderunganuntuk mengambil inisiatif sendiri di dalam memikirkan sesuatudan melakukan tindakan tanpa terlebihdahulu harus diperintah, disuruh, diingatkan,atau dianjurkan orang lain. Anak yang mandiri akan memiliki inisiatif didalam dirinya tanpa harus diminta atau diperintah oleh orang lain. Contohnya seorang anak yang mandiri tidak perlu disuruh oleh gurunya, dia akan membuang sampah pada tempatnya.

\section{2) Mengendalikan Aktivitas yang}

Dilakukan.

Anak yang mandiri mampu mengendalikanpikiran, tindakan dan aktivitas yangdilakukan tanpa harus dipaksa dan ditekan orang lain. Contohnya :seorang anak yang bisa mengatur waktu belajarnya tanpa harus dipaksa oleh orang tuanya.

\section{3) Memberdayakan Kemampuan yang} dimiliki.

Anak mempercayai dan memanfaatkan secara maksimal kemampuan - kemampuan yang dimiliki di dalam menjalankan tugas, mengambil keputusan atau memecahkan masalah, tanpa hatus dibantu oleh orang lain. Contohnya : anak berusaha mengerjakan tugasnya sendiri tanpa harus mengharapkan bantuan gurunya. Menghargai Hasil Kerja Sendiri. Anak mampu menghargai ataumerasa puas 
Jurnal Warna : Jurnal Pendidikan Dan Pembelajaran Anak Usia dini. Maret 2018. Vol 03. No. 01

atas apa yang telah dikerjakan atau dilakukannya. Karena dia telah berusaha melakukan seluruh tugasnya dengan komptensi atau kemampuan yang dimilikinya. Contohnya : anak yang mampu mengerjakan tugasnya sendiri, akan menunjukkan hasil karya nya dengan penuh rasa bangga terhadap dirinya.

Didalam mengembangkan pola kemnadirian pada anak usia dini, seperti dikemukakan oleh Havinghurst bahwa salah satu satu aspek kemandirian didalam diri seorang anak adalah kemampuan seorang anak didalam melakukan pengaturan terhada gejolak emosinya yang tidak lain merupakan kemampuan melakukan regulasi emosi.

Proses pengendalian emosi dapat disebut sebagai regulasi emosi. Regulasi emosi merupakan cara individu untuk menentukan emosi apa yang dirasakan, kapan emosi itu dirasakan dan bagaimana mengekspresikan nya dan mengetahui emosi tersebut. Gross (Song, 2010) mendefinisikan regulasi emosi sebagai cara individu untuk mempengaruhi emosi yang mereka miliki, kapan mereka merasakannya, dan bagaimana mereka mengalami atau mengekspresikan emosi tersebut, selain itu regulasi emosi juga didefinisikan sebagai kemampuan untuk mengevaluasi dan mengubah reaksi -reaksi emosional untuk bertingkah laku tertentu yang sesuai dengan situasi yang sedang terjadi.

Menurut Thomson (1994), regulasi emosi adalah proses intrinsik dan ekstrinsik melalui pemantauan, pengevaluasian dan pemodifikasian, reaksi-reaksi emosi sesuai dengan tujuan dari individu yang bersangkutan. Gross \& John (2003) menyatakan bahwa regulasi emosi adalah pemikiran atau peringatan yang dipengaruhi oleh emosi individu, bagaimana individu mengalami dan mengungkapkan emosinya.Reivich \& Shatte (2002) mengungkapkan bahwa regulasi emosi adalah kemampuan untukmengendalikan emosi, tetap tenang di bawah tekanan. Pengekspresian emosi, baik negatif ataupun positif, merupakan hal yang sehat dankonstruktif asalkan dilakukan dengan tepat.

Menurut Gross dan Thompson ( 2006) ada tiga aspek didalam regulasi emosi, yaitu : 1) pengenalan terhadap emosi diri sendiri. Seseorang diharapkan mampu mengenak dna mengidentifikasi emosi dirinya sendiri, baik emosi negative maupun emosi positif yang ia rasakan. 2) pengaturan emosi. Seseorang harus mampu mengatur pola emosi didalam dirinya. Ada beberapa cara yang dapat dilakukan, salah satunya adalah dengan teknik relaksasi. Pengaturan emsoi ini nantina sangat berkaitan dengan perilaku manusia. 3) 
pengungkapan emosi. Tidak semua orang mampu mengungkapkan apa yang sedang dirasakannya, terutama terkait dengan emosinya. Pengungkapan emosi ini perlu dilakukan dengan cara yag tepat. Banyak orang yang belum mampu mengungkapkan emosinya dengan cara yang tepat, oleh karena itu harus diajarkan sejak dini.

Pola asuh yang diterapkan oleh orang tua merupakan cara dimana orang tua akan mendidik anaknya, termasuk didalamnya bagaimana orang tua menanamkan kemandirian dna kemampuan regulasi emosi didalam diri anaknya.

Melalui penelitian ini, maka peneliti ingin megetahui apakah ada pengaruh antara pola asuh orang tua terhadap kemandirian dan kemampuan regulasi emosi pada anak usia dini.

\section{METODE PENELITIAN}

Rancangan penelitian ini menggunakan pendekatan kuantitatif dalam usaha menguji hipotesis yang telah disusun. Dalam penelitian yang bersifat kuantitatif ini maka proses penelitian banyak menggunakan angka mulai dari pengumpulan, penafsiran dan pengujian hasil.

Penelitian ini terdiri dari dua variabel, yaitu satu variabel bebas dan satu variabel terikat. Variabel bebas (X) gaya pengasuhan dan variabel terikat $(\mathrm{Y})$
Kemandirian dan kemampuan regulasi emosi Pada Anak Usia Dini.

Populasi didalam penelitian ini adalah anak kelas TK B1 dan B2, yang berjumlah 52 siswa, sedangkan populasi didalam penelitian ini berjumlah 26 siswa. Teknik sampling yang digunakan didalam penelitian ini adalah simple random sampling, karena peneliti secara mengambil sample didalam penelitian ini,

Teknik pengumpulan data yang digunakan didalam penelitian ini adalah dengan mengembangkan 3 buah instrumen yang berbentuk skala likert. Peneliti mengembangkan skala pola asuh orang tua yang berisi 20 butir, skala kemandirian anak usia dini yang berisi 26 butir, dan skala regulasi emosi yang berisi 20 butir. Berikut adalah table dari masing-asing skala

\begin{tabular}{|c|c|c|}
\hline Skala & favorable & Unfavorable \\
\hline Pola asuh & 10 & 10 \\
\hline Kemandirian & 13 & 13 \\
\hline $\begin{array}{c}\text { Regulasi } \\
\text { emosi }\end{array}$ & 10 & 10 \\
\hline
\end{tabular}

Teknik analisis data yang digunakan didalam penelitian ini adalah sebagai berikut : uji validitas instrument menggunakan rumus product moment, uji reliabilitas menggunakan rumus alpha cronbach, dan uji anova untuk melihat seberapa besar pengaruh pola asuh orang 
tua terhadap kemandirian dan kemampuan

regulasi emosi pada anak usia dini.

\section{HASIL DAN PEMBAHASAN}

\section{A. Hasil penelitian}

Berdasarkan hasil pengumpulan data yang dilakukan terhadap 26 subyek di TK Santa Maria III Malang, maka ditemukan hasil uji Anova untuk melihat seberapa besar pengaruh pola asuh orang tua terhadap kemandirian dan kemampuan regulasi pada anak usia dini . hasil uji analisa yang dilakukan dengan menggunakan program SPSS 17 tertera didalam tabel berikut ini :

Table 4.1 : Hasil uji hipotesis ( anova) ANOVA $^{b}$

\begin{tabular}{|l|l|l|r|r|r|}
\hline Model & $\begin{array}{l}\text { Sum of } \\
\text { Squares }\end{array}$ & Df & $\begin{array}{c}\text { Mean } \\
\text { Square }\end{array}$ & F & Sig. \\
\hline 1Regression & 2315.506 & 2 & 1157.75 & 8.306 & $.002^{\mathrm{a}}$ \\
& & 3 & & \\
Residual & 3205.879 & 23 & 139.386 & & \\
Total & 5521.385 & 25 & & & \\
\hline
\end{tabular}

a. Predictors: (Constant), regulasi emosi, kemandirian

b. Dependent Variable: pola asuh

Dari hasil perhitungan analisis anova diatas, terlihat bahwa nilai signifikansi yang muncul adalah 0,002, yang berada dibawah 0,05 dengan taraf signifikansi 0,05 (95\%) maka dapat diartikan bahwa pola asuh yang diakukan oleh orang tua memiliki pengaruh yang cukup signifikan terhadap kemandirian dna kemampuan regulasi emosi pad anak usia dini di TK Santa Maria III Malang.

\section{B. Pembahasan}

Pola asuh menurut Casmini (2007) adalah suatu model atau cara orang tua dalam memperlakukan anak, membimbing, dan mendisiplinkan serta melindungi anak dalam mencapai proses pendewasaan, hingga mampu beradaptasi tehadap normanorma yang berlaku di masyarakat. Bentuk dari pola asuh ini bisa berupa perhatian maupun fasilitas yang diberikan orang tua untuk mendukung proses perkembangan anak hingga dewasa. Pola asuh menurut Walgito (2010) adalah suatu model atau cara yang digunakan pendidik untuk mendidik anak dalam usaha membentuk pribadi anak yang sesuai dengan harapan masyarakat pada umumnya. Pendidik disini adalah orang tua yang berperan penting dalam membentuk pola berfikir, sikap dan kepribadian seorang anak ketika dewasa. Bentuk dari pola asuh ini bisa berupa perhatian maupun fasilitas yang mendukung proses perkembangan anak.

Kenyataan yang terjadi didalam kehidupana keluarga adalah orang tua kurang memahami dampak dari pola asuh yang diterapkan terhadap anak-anaknya. Pengasuhan yang baik membutuhkan waktu dan usaha. Orang tua tidak bisa melakukannya dalam waktu yang singkat, bukan hanya jumlah waktu yang dihabiskan orang tua bersama anak tetapi yang penting bagi perkembangan anak adalah bagaimana 
kualitas pengasuhan yang diterapkan oleh orang tua.

Setiap orang tua memiliki kulaitas pengasuhan yang berbeda-beda, didalam menjalankan proses pengasuhan terhadap anak orang tua dapat memberikan kesempatan kepada anak untuk melayani kebutuhan dirinya dimuali dari hal-hal yang sederhana, seperti halnya : ketika anak berusia satu tahun, anak mulai belajar untuk memegang sendok makan dan memasukan makanan kedalam mulutnya secara mandiri walaupun tetap didalam pengawasan orang tuanya.

Didalam menerapkan pola kemandirian orang tua juga memiliki cara yang berbedabeda. Ada orang tua yang memberikan kesempatan kepada anaknya untuk melakukan kegiatan sehari-harinya secara mandiri, yang dipercaya merupakan proses belajar bagi anak, tetapi ada pula oran tua yang cenderung memberikan bantuan kepada anaknya.

Kemandirian adalah suatu sikap individu yang diperoleh secara kumulatif selama perkembangan, dimana individu akan terus belajar untuk bersikap mandiri dalam menghadapi berbagai situasi lingkungan, sehingga individu pada akhirnya akan mampu berfikir dan bertindak sendiri dengan kemandiriannya (Tjandraningtyas, 2004).
Kemandirian adalah suatu upaya yang dilakukan dan dimaksudkan untuk melatih anak dalam memecahkan masalahnya (Yuliani, 2007). Parker mengatakan bahwa kemandirian adalah kemampuan untuk mengelola semua milik kita, tahu bagaimana mengelola waktu, berjalan dan berfikir secara mandiri, desertai kemampuan untuk mengambil resiko dan memecahkan masalah (Debora, 2006).

Menurut Diane Trister Dogde kemandirian anak usia dini dapat dilihat dari pembiasaan dan kemampuan anak dalam kemampuan fisik, percaya diri, bertanggungjawab, disiplin, pandai bergaul, mau berbagi, mengendalikan emosi (Diane, 2008). Selanjutnya Brewer juga menyatakan bahwa kemandirian anak Taman Kanak-kanak indikatornya adalah pembiasaan yang terdiri dari kemampuan fisik, percaya diri, bertanggungjawab, disiplin, pandai bergaul, mau berbagi, mengendalikan emosi (Brewer, 2007).

Didalam mengendalikan emosi, seseeorang perlu memiliki kemampuan untuk melakukan regulasi emosi. Gross ( Song, 2010) mengemukakan bahwa regulasi emosi dapat diartikan sebagai sebuah cara didalam diri individu untuk mempengaruhi emosi yang mereka miliki, kapan mereka merasakannya, dan bagaimana mereka mengalami atau mengekspresikan emosi tersebut, selain itu regulasi emosi juga 
didefinisikan sebagai kemampuan untuk mengevaluasi dan mengubah reaksi -reaksi emosional untuk bertingkah laku tertentu yang sesuai dengan situasi yang sedang terjadi.

Orang tua harus mengarahkan anaknya didalam melakukan regulasi emosi, dimulai dari hal yang paling sederhana yaitu bagaimana orang tua membantu anaknya didalam mengenal emosi atau perasaan yang dirasakan oleh anaknya. Didalam memehami perasaan anak perlu diberi pemahaman tentang macam-macam emosi yang bisa saja muncul didalam diri mereka. Diharapkan setelah anak mengenal, anak mampu mengutarakan apa yang sedang dirasakannya. Orang tua juga harus mengajarkan kepada anaknya tentang mengontrol reaksi-reaksi emosi yang muncul, sehingga regulasi emsoi didalam diri anak tersebut dapat berjalan dengan baik.

\section{KESIMPULAN}

Berdasarkan hasil penelitian mengenai pengaruh pola asuh tua terhadap kemandirian dan kemampuan regulasi emosi anak usia dini, maka dapat disimpulan bahwa pola asuh orang tua berpengaruh secara signifikan terhadap kemandirian dan kemampuan regulasi emosi pada anak usia dini. Hal tersebut terlihat dari hasil uji anova yang dilakukan antara variabel bebas yaitu : pola asuh orang tua, dengan variabel terikat, yaitu : kemandirian dan regulasi emosi yang menunjukkan angka signifikansi : 0.002, dengan taraf signifikansi 0.5 ( 95\%), dengan hasil tersebut, dapat disimpulkan pula bahwa Ha diterima dan H0 ditolak, yang menyatakan bawa ada pengaruh antara pola asuh orang tua terhadap kemandirian dan kemampuan regulasi emosi pada anak usia dini.

\section{DAFTAR PUSTAKA}

Arikunto, Suharsimi. 2006. Prosedur Penelitian.Jakarta: Rineka Cipta.

Casmini. (2007). Emotional parenting; Dasardasar Pengasuhan KecerdasanEmosi Anak. Yogyakarta: Nuansa Aksara

Desmita. ( 2009). Perkembangan Peserta didik. Bandung: Rosda Karya

Dewanggi M, dkk. ( 2012). Pengasuhan orang tua dan kemandirian anak usia 3-5 tahun berdasarkan gender di kampung adat Urug . Bogor. Institut Pertanian Bogor

Hadi, S. (2004). Analisis Regresi. Yogyakarta: Andi Offset.

Hoghuni, M. (2004). Handbook of Parenting. London.

Hurlock, B.E. (1999). Psikologi Perkembangan: Suatu Pendekatan Sepanjamg.Rentang Kehidupan. Ed. 5. Jakarta: Erlangga.

Liza Marini. \& Elvi Andriani. (2005). Perbedaan Asertivitas Remaja Ditinjau dari Pola Asuh Orang Tua. PSIKOLogia.Vol: 1, No: 2. 
Jurnal Warna : Jurnal Pendidikan Dan Pembelajaran Anak Usia dini. Maret 2018. Vol 03. No. 01

Moh. Shochib. (2010). Pola Asuh Orang Tua Dalam Membantu Mengembangan Displin Diri sebagai Pribadi yang Berkarakter. Jakarta: Rineka Cipta.

Santrock, John W. 2007. Life-Span Development . Jilid I \& II. Jakarta: Erlangga.

Song. (2010). Healty responses to children's emotion. New York: Routledge.

Suardani, Luh,dkk.( 2016).Perbedaan tingkat kemandirian anak usia 5-6 tahun dilihat dari status pekerjaan ibu di keluarah Banyuning. Singaraja. Universitas Pendidikan Ganesha

Sugiyono .(2016). Metode Penelitian Kuantitatif, Kualitatif dan $R$ \& D. Bandung:Penerbit Alfabeta.

Walgito, B. (2010). Pengantar Psikologi Umum. Jakarta: Penerbit Andi

Yamin.Sabari (2013). Panduan PAUD (Pendidikan Anak Usia Dini). Jambi 